\title{
COVID-19 perception and preventive behaviors: A descriptive, comparative study by severity and perceived risk
}

\author{
Isaías Vicente Lugo-González, ${ }^{1,2}$ Margarita Fernández-Vega ${ }^{3}$ Leonardo Reynoso-Erazo, ${ }^{1,2}$ \\ Ana Leticia Becerra-Gálvez, ${ }^{2}$ Yuma Yoaly Pérez-Bautista
}

División de Investigación y Posgrado, Facultad de Estudios Superiores Iztacala, UNAM, Ciudad de México, México.

2 Residencia en Medicina Conductual, Facultad de Estudios Superiores Iztacala, UNAM, Ciudad de México, México.

3 Instituto Nacional de Enfermedades Respiratorias Ismael Cosío Villegas (INER), Ciudad de México, México.

\section{Correspondence:}

Isaías Vicente Lugo-González

Unidad de Investigación Interdisciplinaria en Ciencias de la Salud y Educación (UIICSE). Facultad de Estudios Superiores Iztacala, UNAM. Av. De los Barrios s/n,

Los Reyes Iztacala,

54090, Tlalnepantla,

Estado de México, México.

Phone: 55 2139-1096

Email: isaiasvlg@comunidad.unam.mx

Received: 12 June 2020

Accepted: 18 August 2020

\section{Citation:}

Lugo-González I. V., Fernández-Vega, M., Reynoso-Erazo, L., Becerra-Gálvez, A. L., \& Pérez-Bautista, Y. Y. (2020). COVID-19 perception and preventive behaviors: A descriptive, comparative study by severity and perceived risk. Salud Mental, 43(6), 285-292.

DOI: $10.17711 /$ SM.0185-3325.2020.039

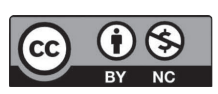

\begin{abstract}
Introduction. The prevention of COVID-19 infections involves the implementation of behaviors to reduce risk and protect health. However, engaging in these behaviors depends on the perception of the threat posed by the illness. Previous research shows the importance of illness perception in the case of communicable and non-communicable diseases, showing that they can change depending on the severity and risk attributed to them. Objective. Compare the illness perception and the practice of preventive and exposure behavior based on the severity and the risk attributed to COVID-19 at the end of phase 1 and the beginning of phase 2 of the pandemic in Mexico. Method. By means of a chain sampling, a comparative study was conducted in which an evaluation battery was disseminated through e-mail and social networks. Results. It was found that evaluating COVID-19 as a serious disease and perceiving oneself as being at risk of contracting it had small and moderate effects on the perception of the consequences of the illness $(r=.34 ; r=.26)$, emotional impact $(r=.32 ; r=.25)$, personal control $(r=.24)$ and engagement in preventive $(r=.05)$, and exposure behaviors $(r=.07 ; r=.07)$. Discussion and conclusion. This article shows the relevance of the perceptual variables that impact concern due to the social and emotional consequences of COVID-19, as well as those that encourage preventive behaviors and the minimization of exposure behavior.
\end{abstract}

Keywords: COVID-19, perception, cognition, behavior, risk, self-regulation.

\section{RESUMEN}

Introducción. Si bien la prevención de contagios de COVID-19 supone la implementación de comportamientos para reducir el riesgo y proteger la salud, la práctica de estas conductas está en función de la percepción que se tenga sobre la amenaza de la enfermedad. Investigaciones previas evidencian la importancia de la percepción de enfermedad cuando se trata de padecimientos transmisibles y no transmisibles, señalando que ésta puede modificarse en función de la gravedad y el riesgo atribuido. Objetivo. Comparar la percepción de enfermedad y la práctica de conductas de prevención y exposición con base en la gravedad y el riesgo atribuidos al COVID-19 al término de la fase 1 e inicio de la fase 2 de la pandemia en México. Método. A partir de un muestreo en cadena, se realizó un estudio comparativo en el que se diseminó una batería de evaluación por medio de correo electrónico y redes sociales. Resultados. Se encontró que evaluar el COVID-19 como una enfermedad grave y percibirse en riesgo de contraerla tiene efectos moderados y leves, respectivamente, sobre la percepción de las consecuencias de la enfermedad $(r=.34 ; r=.26)$, el impacto emocional $(r=.32 ; r=.25)$, el control personal $(r=.24)$ y la práctica de conductas de prevención $(r=.05)$ y exposición $(r=.07 ; r=.07)$. Discusión y conclusión. El presente estudio muestra la relevancia de las variables perceptuales que impactan en la preocupación por consecuencias sociales y emocionales del COVID-19, así como de aquellas que favorecen las conductas de prevención y la minimización de conducta de exposición.

Palabras clave: COVID-19, percepción, cognición, conducta, riesgo, autorregulación. 


\section{INTRODUCTION}

In early December 2019, the emergence of a betacoronavirus, corresponding to an increase in the number of pneumonia cases in China, was reported. Most of those diagnosed reported having gone to a seafood market and purchasing various species of live animals as an exposure factor. The disease spread quickly locally, then to other parts of China, and subsequently globally (Dong et al., 2020; Gandhi, Lynch, \& del Rio, 2020; Verity et al., 2020).

In early January 2020, this coronavirus was identified in samples from alveolar lavage fluid performed on patients diagnosed with pneumonia. It was subsequently identified by the China Center for Disease Control and Prevention as the disease causative agent. Days later, on January 7, 2020, the World Health Organization (WHO) provisionally named the new coronavirus 2019-nCoV. Afterwards, it renamed it SARS-CoV-2, which causes the COVID-19 disease (Cascella, Rajnik, Cuomo, Dulebohn, \& Di Napoli, 2020; Dong et al., 2020; Verity et al., 2020).

COVID-19 has an incubation period of seven to 10 days, with its main symptoms being fever, cough, dyspnea, rhinorrhea, hypogeusia, anosmia, and, in some cases myalgia, headache, or odynophagia. In its most severe form, it is characterized by hyperinflammation, cytokine storm, and high cardiac injury biomarkers (Cascella et al., 2020; Dong et al., 2020; Verity et al., 2020). In Mexico, the first infected patient was reported on February 28, 2020 (Epidemic Stats, 2020).

For the prevention of COVID-19 infections, a number of behavioral measures have been established, such as social distancing (staying home, only going out for essential activities, avoiding crowds), individual protection and hygiene measures (hand washing, cleaning surfaces and objects), and social coexistence behaviors (sneezing into the crook of your arm, avoiding kissing, handshakes, and hugs) (Cascella et al., 2020; Holmes et al., 2020; Secretaría de Salud [SSa], 2020; Chater et al., 2020).

Based on these types of measures and in accordance with the Common Sense Model of Illness Perception (CSM) (Leventhal, Meyer, \& Nerenz, 1980), engaging in these behaviors will depend on the way COVID-19 is perceived, the severity attributed to the disease, the experiences a person has had in relation to the disease, and the information available in the immediate context, as well as the perceived probability of becoming ill (Rubin, Potts, \& Michie, 2010; Taylor, 2019).

Given the advances in it (Moss-Morris et al., 2002; Broadbent, Petrie, Main, \& Weinman, 2006), the CSM (Leventhal et al., 1980), could help define the way people understand COVID-19. Although this process model makes it possible to understand the self-regulation of health and disease behavior in a global way (perception-behavior-results), its first stage (perceptual stage) considers a concep- tual structure with various sub-dimensions that could shed light on the perception of COVID-19.

The dimensions constituting this stage are the cognitive and emotional perception of the disease, subdivided into (Broadbent et al., 2006; Leventhal et al., 1980; Moss-Morris et al., 2002): Identity: perceptual experience of the disease, type, place, and amount of symptoms or somatic sensations associated with it; temporality: perception of duration (acute, chronic, or cyclical); causes: perceived reasons of what caused the disease; consequences: perceived and experienced repercussions in various areas of life; personal control: perceived ability to control the disease; control of treatment: perceived impact treatment will have on the condition; coherence: clarity with which the disease is understood; and emotional perception: perception of emotional repercussions associated with the disease.

There are different forms of evaluation for the illness perception, such as drawings, unique items, and evaluation scales. For a detailed review, see Petrie and Weinman (2006), Petrie and Weinman (2012), Pacheco-Huergo et al. (2012), and Mora and McAndrew (2013).

Measurement scales include the Revised Illness Perception Questionnaire (IPQ-R, Moss-Morris et al., 2002), divided into three sections: 1 . identity assessment; 2 . scales of personal control, treatment control, acute/chronic temporality, cyclical course, consequences, emotional perception, and coherence; and 3. scale of causes. The IPQ-R was initially validated in patients with chronic diseases, although versions for infectious and acute diseases are now available (Figueiras \& Alves, 2007; Hagger \& Orbell, 2005; Wu et al., 2018). This instrument already has reliability and validity data in Mexico for patients with asthma (Lugo-González, Fernández-Vega, Pérez-Bautista, \& Vega-Valero, 2020).

Another instrument is the Brief Illness Perception Questionnaire (BIPQ, Broadbent et al., 2006), which consists of nine items on the CSM sub-dimensions. Derived from this instrument, evaluations have been adapted and research data obtained in Spanish in the context of COVID-19 (Molero-Jurado, Herrera-Peco, Pérez-Fuentes, \& Gázquez-Linares, 2020; Pérez-Fuentes et al., 2020).

Given that the COVID-19 pandemic is having emotional, social, and economic consequences worldwide (Brooks et al., 2020; Douglas, Katikireddi, Taulbut, McKee, \& McCartney, 2020; Holmes et al., 2020; Lai et al., 2020; Pérez-Gay et al., 2020), it was considered pertinent to conduct an evaluation on the perception of COVID-19 in Mexican population using the IPQ-R already validated in this country. Accordingly, the objective of this study was to evaluate and compare the disease perception and the practice of prevention and exposure behaviors based on the severity and risk attributed to COVID-19 in Mexican adolescents and adults. 


\section{METHOD}

\section{Design}

A descriptive, comparative study was conducted, based on the description by Méndez, Namihira, Moreno, and Sosa (2001).

\section{Participants}

Using chain or network samplings (Hernández-Sampieri, Fernández-Collado, \& Baptista-Lucio, 2014), 1,560 adolescents and adults from various Mexican states with an average age of 31.88 years $(S D=11,045$, Range $=15-77$ years $)$ were invited to participate voluntarily.

\section{Instruments}

Socio-demographic data card: Set of items to obtain information on residence, family, educational, occupational data, and use of information media, among others.

Revised Illness Perception Questionnaire (IPQ-R; Moss-Morris et al., 2002): Instrument to assess cognitive and emotional illness perception. The version validated in Mexico (Lugo-González et al., 2020) has evidence of reliability with Cronbach's alpha and data with structural, convergent, and divergent validity. For this paper, the identity assessment was adapted with a list of 12 symptoms associated with COVID-19, as well as 16 items corresponding to the sub-dimensions of temporality, consequences, personal control, coherence and emotional perception (modifying the name of the disease). The scale has a four-point Likerttype response format ranging from totally disagree to totally agree. The reliability analysis showed a Cronbach's alpha of .886 while the evidence of structural validity indicated a three-factor structure (emotional perception, consequences, and personal control) that explain $49.121 \%$ of the variance $\left(K M O=.922, \mathrm{X}^{2}=10487.243, p<.01\right)$ with six items for the first factor, seven for the second and three for the third.

COVID-19 Preventive and Exposure Behavior Scale (PEBS-COVID19): Behavioral scale designed ad hoc for this study and based on the recommendations of the SSa (2020), comprising 11 items evaluating the frequency of preventive behaviors (hand washing, surface cleaning, hand-to-face contact, sneezing into the crook of your arm, and social distancing) and exposure (physical contact, handshaking, and greeting people with a kiss). The scale has a four-point Likert-type response format that goes from I always do it this way to I never do it this way. The reliability analysis showed a Cronbach's alpha of .796 while the evidence of structural validity corroborated a bifactorial structure that explains 41.936 of the variance $(K M O=.827$, $\mathrm{X}^{2}=5046.614, p<.01$ ) with eight items for the first factor (prevention), and three for the second (exposure).
Assessment of perception of severity and risk: Items that assess the severity attributed to COVID-19, as well as the perceived risk of contracting the disease. Both items are answered on a four-point Likert-type scale ranging from totally disagree to totally agree.

\section{Procedure}

The evaluation was conducted on Google-Forms Online ${ }^{\circledR}$ and distributed through email and social networks such as Facebook $^{\circledR}$ and WhatsApp ${ }^{\circledR}$ from March 22 to April 4, the week all educational centers in Mexico closed and one day before the official start of the National Healthy Distance Day (SSa, 2020). This evaluation was active during the last week of phase 1 and the first week of phase 2 of the COVID-19 pandemic in Mexico.

\section{Statistical analysis}

The statistical program SPSS version 24 for Windows was used. Data normality analyses were conducted to determine the type of statistic to use for the purposes of comparing the variables. Given the sample size and the analysis program, the Shapiro-Wilk $(W)$ test was used, based on the recommendations of Pedrosa, Juarros-Basterretxea, Robles-Fernández, Basteiro, and García-Cueto (2015). Subsequently, descriptive statistics calculations (measures of dispersion and central tendency) were carried out for the sociodemographic variables, perception of COVID-19, prevention and exposure behaviors, and perceived severity and risk.

The comparative analysis was carried out by constructing categorical variables of severity (severe/non-severe) and risk perception (risk/non-risk) and using the Mann-Whitney U statistical test, considering a $p<.05$ for significant differences between groups. Effect size (Rosenthal's $r$ ) was calculated with the following cut-off points: small effect $(.1$ to $<.3)$; moderate effect $(.3$ to $<.5)$; and large effect $(\geq .5)$ (Cohen, 1988), using the following equation: $(r=z / \sqrt{n 1+n 2})$ (Field, 2009).

\section{Ethical considerations}

Participants could answer the form after they had given their informed consent. The project was evaluated and accepted by the research ethics committee of the Instituto Nacional de Enfermedades Respiratorias (INER), with the following registration number assigned by the committee: S02-20.

\section{RESULTS}

\section{Descriptive analysis}

Data in the normality tests showed that none of the variables included behaved in a normal way, since the values 
Table 1

Sociodemographic characteristics of participants

\begin{tabular}{lrc}
\hline Variables & $n$ & $\%$ \\
\hline Sex & 1,176 & 75.4 \\
$\quad$ Female & 384 & 24.6 \\
$\quad$ Male & & \\
Place of residence & 597 & 38.3 \\
$\quad$ Mexico City & 553 & 35.4 \\
$\quad$ State of Mexico & 410 & 26.3 \\
Other states & & \\
Marital status & 885 & 37.5 \\
Single & 340 & 31.1 \\
Married & 239 & 15.3 \\
Partnered & 96 & 16.1 \\
$\quad$ Other & & \\
Educational level & 1106 & 70.9 \\
Bachelor's degree & 207 & 13.3 \\
High school & 156 & 10 \\
Graduate & 91 & 5.8 \\
$\quad$ Other & & \\
\hline
\end{tabular}

in the various sub-dimensions of disease perception ranged from $W=.860$ to $.976(g l=1560 ; p<.01)$ and the values of prevention behaviors from $W=.894$ to $.968(\mathrm{gl}=1560$; $p<.01$ ), while the value of perception of severity was $W=$ $.873(g l=1560 ; p<.01)$ and risk perception was $W=.964$ $(g l=1560 ; p<.01)$.

Table 1 shows the sociodemographic characteristics of the participants, where it is observed that they were mostly women (75\%), residents of Mexico City and the State of Mexico (73.7\%), single (37.5\%), and had completed higher education $(80.9 \%)$.

Table 2 shows the descriptive data of the participants in terms of perception of COVID-19, the self-report on preventive and exposure behaviors and severity and perceived risk.
Table 2

Descriptive results of perception of COVID-19, preventive and exposure risks and severity and perceived risk

\begin{tabular}{llrrrr}
\hline Instrument & \multicolumn{1}{c}{ Subdimension } & Mdn & IR & Min & Max \\
\hline IPQ-R-COVID19 & Identity & 7 & 3 & 0 & 12 \\
& Consequences & 20 & 5 & 7 & 28 \\
& Personal control & 9 & 3 & 3 & 12 \\
& Emotional perception & 14 & 7 & 6 & 24 \\
PEBS-COVID19 & Preventive behaviors & 25 & 6 & 8 & 32 \\
& Exposure behaviors & 6 & 4 & 3 & 12 \\
Severity & & 3 & 1 & 1 & 4 \\
Risk & & 2 & 1 & 1 & 4 \\
\hline
\end{tabular}

Note: Mdn: Median; IR: Interquartile range.

The results show that seven of the 12 main symptoms associated with COVID-19 (fever, dyspnea, dry cough, headache, sore throat, tiredness, and muscle and joint pain) show a positive identification in over $50 \%$ of participants. Conversely, the symptoms that were identified to a lesser extent by participants were: sneezing, nasal congestion, runny nose, itchy eyes, and cough with phlegm (Figure 1).

It can also be seen that one of the main concerns of participants is the impact (perceived) the disease will have given the time it will last, the difficulty of understanding and controlling it, and the effect on people's lives, the family, the economy, and emotional stability (sub-dimension of consequences). This last aspect is shown in the emotional perception sub-dimension, where the impact of COVID-19 is reported in experiences of worry, anxiety, anger, and mood changes.

Despite the emotional impact and perceived consequences of COVID-19, participants reported a high perception of personal control to avoid contracting the disease, which apparently coincides with the high self-report of preventive behavior (hand washing, social distancing, protec-

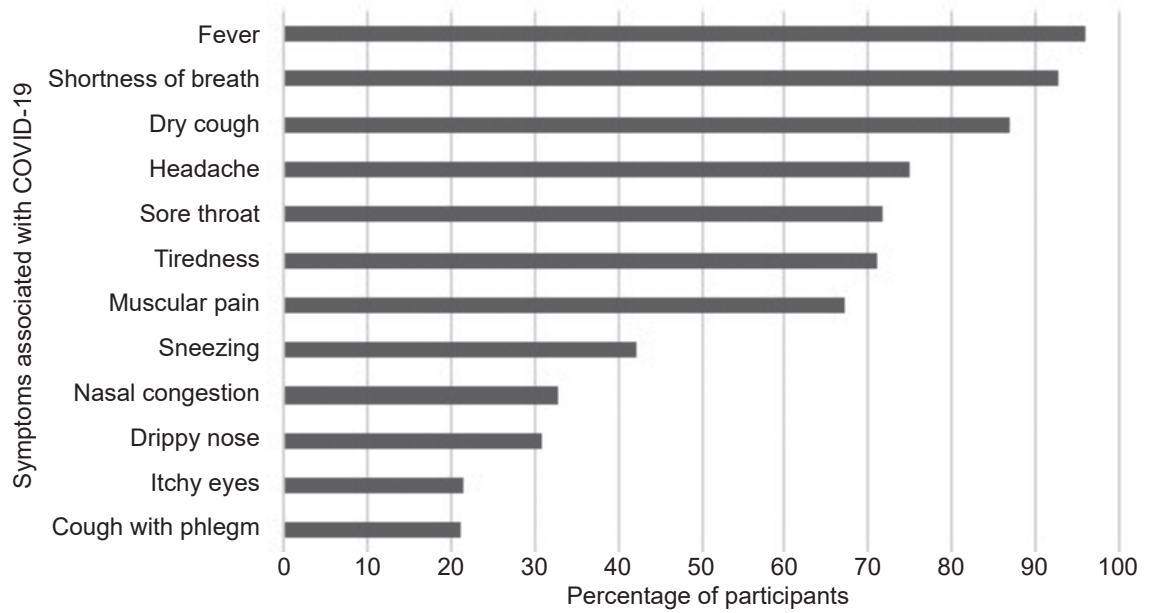

Figure 1. Description of symptoms associated with COVID-19 (Subdimension of identity in CSM). 
Table 3

Comparison of perception of COVID-19 and preventive behaviors between severe and non-severe categories

\begin{tabular}{|c|c|c|c|c|c|c|c|c|c|}
\hline \multirow[b]{2}{*}{ Instrument } & \multirow[b]{2}{*}{ Contrast } & \multicolumn{2}{|c|}{$\begin{array}{c}\text { Severe } \\
(n=946)\end{array}$} & \multicolumn{2}{|c|}{$\begin{array}{c}\text { Not severe } \\
(n=614)\end{array}$} & \multirow[b]{2}{*}{$U$} & \multirow[b]{2}{*}{ Z } & \multirow[b]{2}{*}{$p$} & \multirow[b]{2}{*}{$r$} \\
\hline & & $M d n$ & $I R$ & $M d n$ & IR & & & & \\
\hline \multirow[t]{4}{*}{ IPQ-R-COVID19 } & Identity & 7 & 3 & 7 & 2 & 282864.000 & -.879 & .379 & .02 \\
\hline & Consequences & 20 & 5 & 18 & 7 & 172306.000 & -13.634 & .000 & .34 \\
\hline & Personal control & 10 & 2 & 9 & 4 & 208348.000 & -9.565 & .000 & .24 \\
\hline & Emotional perception & 16 & 5 & 12 & 7 & 179794.000 & -12.754 & .000 & .32 \\
\hline \multirow[t]{2}{*}{ PEBS-COVID19 } & Preventive behaviors & 25 & 6 & 25 & 7 & 272417.000 & -2.076 & .038 & .05 \\
\hline & Exposure behaviors & 6 & 4 & 7 & 4 & 264961.000 & -2.953 & .003 & .07 \\
\hline
\end{tabular}

Note: Mdn: Median; IR: Interquartile Range; $r$ : Effect size Rosenthal's r.

tion at home, sneezing into your elbow, and avoiding touching your face) and low exposure behavior (shaking hands and/or kissing, and hugging others).

Finally, the data on severity and perceived risk show that in general, participants regard COVID-19 as a serious disease, yet do not consider themselves at risk of becoming ill.

\section{Comparative analyses}

Once the severity and risk categories had been constructed, 946 participants were located who declared that COVID-19 was a serious disease and 614 that it was not (Table 3). Likewise, 437 perceived themselves as being at risk of becoming ill with COVID-19 while 1123 did not (Table 4).

A comparison between severe/non-severe and the sub-dimensions of perception of COVID-19 showed that those who consider the disease serious perceive greater consequences $(M d n=20)$ and are more emotionally affected $(M d n=16)$ than those who do not consider it serious ( $M d n=18$ and $M d n=12$, respectively). In fact, this assessment of severity has a moderate effect on the perception of consequences and emotional effects $(r=.34$ and $r=.32$, respectively).

However, perceiving COVID-19 as a serious disease also fosters a greater perception of personal control $(M d n=10)$ to avoid getting the disease, although the effect is small $(r=.24)$.
Regarding preventive behaviors, it was observed that those who consider it serious engage in this type of behaviors more frequently, compared to those who do not regard it as serious. Despite this, the effect of the perception of severity on preventive behaviors has only a small effect. A similar result was found in exposure behaviors, where those who perceive COVID-19 as not serious engage in this type of behavior more frequently.

Regarding perceived risk, it was found that those who consider themselves to be at risk of becoming ill from COVID-19 perceive greater consequences $(M d n=21)$ and are emotionally more affected $(M d n=16)$ than those who do not perceive themselves to be at risk $(M d n=19$ and $M d n=13$, respectively); although the effect is small ( $r=.26$ and $r=.25$, respectively).

In much the same way as in the severity assessment, in perceived risk it is found that those who do not perceive themselves at risk of becoming ill from COVID-19 engage in exposure behaviors more frequently $(M d n=7)$, also with a very small effect $(r=.07)$.

\section{DISCUSSION AND CONCLUSION}

The results found that participants identified the 12 COVID-19 symptoms on the list although, in general, they identified seven of them more often. This is striking since,

Table 4

Comparison of perception of COVID-19 and preventive behaviors between categories of perceived and non-perceived risk

\begin{tabular}{|c|c|c|c|c|c|c|c|c|c|}
\hline \multirow[b]{2}{*}{ Instrument } & \multirow[b]{2}{*}{ Contrast } & \multicolumn{2}{|c|}{$\begin{array}{c}\text { Risk } \\
(n=437)\end{array}$} & \multicolumn{2}{|c|}{$\begin{array}{c}\text { No risk } \\
(n=1123)\end{array}$} & \multirow[b]{2}{*}{$U$} & \multirow[b]{2}{*}{$Z$} & \multirow[b]{2}{*}{$p$} & \multirow[b]{2}{*}{$r$} \\
\hline & & $M d n$ & IR & $M d n$ & $I R$ & & & & \\
\hline \multirow[t]{4}{*}{ IPQ-R-COVID19 } & Identity & 7 & 3 & 7 & 2 & 235909.000 & -1.198 & .231 & .03 \\
\hline & Consequences & 21 & 4 & 19 & 5 & 162841.000 & -10.364 & .000 & .26 \\
\hline & Personal control & 9 & 3 & 9 & 3 & 229766.000 & -1.979 & .431 & .05 \\
\hline & Emotional perception & 16 & 5 & 13 & 7 & 165727.500 & -9.989 & .000 & .25 \\
\hline \multirow[t]{2}{*}{ PEBS-COVID19 } & Preventive behaviors & 25 & 6 & 25 & 6 & 242189.000 & -.400 & .689 & .01 \\
\hline & Exposure behaviors & 6 & 4 & 7 & 4 & 221787.000 & -2.967 & .003 & .07 \\
\hline
\end{tabular}

Note: Mdn: Median; IR: Interquartile range; $r$. Effect size Rosenthal's $r$. 
on the one hand, the latter are the most frequently reported ones in the medical literature (Gandhi et al., 2020) and the ones most widely disseminated in the media and official sources (SSa, 2020), which could reflect the general contact of participants with various sources of information on COVID-19. In fact, regardless of the severity and attributed risk, identification of symptoms is similar between groups.

At the same time, when having to discriminate between such a wide range of symptoms, there could be confusion over their importance or a minimization of their severity, as noted by Lunn et al. (2020), especially if it is mistakenly thought that COVID-19 symptoms are similar to those of the common cold and range from mild to moderate (National Institute of Allergy and Infectious Diseases [NIAID], 2020).

However, the duration of the pandemic and the economic and social consequences appear to be two of the elements that most concern participants. It should be recalled that in Mexico, mitigation measures began ahead of time to ensure that transmission took place gradually, which meant that an extension was planned for the length of time of social distancing and the return to normality (SSa, 2020).

In this context, various emotional consequences would undoubtedly be expected in the population, since these occur after a prolonged time of social distancing, as shown by the findings during the outbreaks of the SARS virus in 2003 (Cava, Fay, Beanlands, McCay, \& Wignall, 2005; Day, Park, Madras, Gumel, \& Wu, 2006) and of COVID-19 in Spain (Sandín, Valiente, García-Escalera, \& Chorot, 2020) and China (Dai, Hu, Xiong, Qiu, \& Yuan, 2020; Wang et al., 2020).

The emotional perception results indicate that a significant number of participants were experiencing emotional sequelae, although the general data show they were only moderately impacted. This could be attributed to the moment of data collection (phase 1 and phase 2), meaning that a set of expected psychological responses is involved, which coincides with the study by Wang et al. (2020) during the initial phase of COVID-19 in China, El Salvador (Orellana \& Orellana, 2020), and Mexico (González Ramírez, Martínez Arriaga, Hernández-Gonzalez, \& De la Roca-Chiapas, 2020).

The evaluation of consequences, the emotional impact, and risk perception are expected to evolve to more adverse scenarios, as has been the case in Mexico and other parts of the world in the H1N1 influenza in 2009 (Rubin, Amlôt, Page, \& Wessely, 2009; Rubin et al., 2010), the Ebola outbreak in 2014 (Garfin, Silver, \& Holman, 2020), the MERS outbreak in 2015 (Yang \& Cho, 2017), and during COVID-19 (Muñiz \& Corduneanu, 2020).

It is worth noting that despite the negative experiences and perceptions at an emotional level experienced by participants, a high perception of personal control over preventing the spread of COVID-19 was also expressed. This variable should also be considered, since it is causally linked to preventive behaviors during the pandemic and the prevention of emotional sequelae (Bashirian et al., 2020; Shacham et al., 2020).

Regarding prevention and exposure behaviors, it was found that the vast majority reported engaging in preventive and protective behaviors. Conversely, they declared that they continued to engage in exposure behaviors such as shaking hands, kissing, and hugging other people to a lesser extent. This is striking since the vast majority did not consider themselves to be at risk of becoming infected with COVID-19 $(n=1123)$. This low risk perception is a determinant for failing to engage in preventive behaviors during COVID-19 and other pandemics (Rubin et al., 2010; Urzúa, Vera-Villarroel, Caqueo-Urízar, \& Polanco-Carrasco, 2020). For this reason, desirable responses in social terms should not be ignored, since, where protective and adherence behaviors are concerned, self-reporting of the latter tends to be overestimated (Stirratt et al., 2015).

In this respect, there is an undeniable need to encourage the maintenance of preventive behaviors throughout the pandemic. It is therefore essential to implement behavioral programs that will inform, increase the perception of severity and risk, and model, shape and reinforce preventive behaviors, guaranteeing their morphological correspondence and a functional environment to implement them and identify contingent positive results (Chater et al., 2020; Lunn et al., 2020; Urzúa et al., 2020; West, Michie, Rubin, \& Amlôt, 2020).

Limitations of the study include the fact that the evaluation was conducted at a distance, including socially valued responses. Despite this, Stirratt et al. (2015) have widely recommended distance evaluations through the Internet, so that the interviewer or administrator does not influence the participant's answers. In fact, Pérez-Bautista and Lugo-González (2017) showed that there are no statistically significant differences in the answers regarding protective behaviors between participants who answer instruments using pencil and paper and via Google ${ }^{\circledR}$ form.

In addition to the above, due to the fact that the sampling was non-probabilistic, there could be problems regarding the sample distribution, since, in the present study, most respondents were single women, from the center of the country, and with a high educational level. However, it suffices to review the sample distribution and characteristics of the participants in current research on COVID-19 to see that these data are consistent in various parts of the world, with women's responses ranging from $52 \%$ to $80 \%$ (Dai et al., 2020; González Ramírez et al., 2020; Molero-Jurado et al., 2020; Muñiz \& Corduneanu, 2020; Orellana \& Orellana, 2020; Shacham et al., 2020).

\section{Financing}

None.

\section{Conflict of interest}

The authors indicate that there is no conflicts of interest. 


\section{REFERENCES}

Bashirian, S., Jenabi, E., Khazaei, S., Barati, M., Karimi-Shahanjarini, A., Zareian, S., ... Moeini, B. (2020). Factors associated with preventive behaviours of COVID-19 among hospital staff in Iran in 2020: an application of the Protection Motivation Theory. Journal of Hospital Infection, 105(3), 430-433 doi: 10.1016/j.jhin.2020.04.035

Broadbent, E., Petrie, K., Main, J., \& Weinman, J. (2006). The brief illness perception questionnaire. Journal of Psychosomatic Research, 60(6), 631-637. doi: 10.1016/j.jpsychores.2005.10.020

Brooks, S. K., Webster, R. K., Smith, L. E., Woodland, L., Wessely, S., Greenberg, N., \& Rubin, G. J. (2020). The psychological impact of quarantine and how to reduce it: rapid review of the evidence. The Lancet, 395(10227), 912-920. doi: 10.1016/S0140-6736(20)30460-8

Cascella, M., Rajnik, M., Cuomo, A., Dulebohn, S. C., \& Di Napoli, R. (2020). Features, evaluation, and treatment coronavirus (COVID-19), Statpearls [internet]. Treasure Island, FL: StatPearls Publishing.

Cava, M. A., Fay, K. E., Beanlands, H. J., McCay, E. A., \& Wignall, R. (2005). Risk perception and compliance with quarantine during the SARS outbreak. Journal of Nursing Scholarship, 37(4), 343-347. doi: 10.1111/j.1547-5069.2005.00059.x

Chater, A. M., Arden, M., Armitage, C., Byrne-Davis, L., Chadwick, P., Drury, J., ... Storr, J. (2020). Behavioural science and disease prevention: psychological guidance. British Psychological Society.

Cohen, J. (1988). Statistical power analysis for the behavioral sciences, (2nd Ed.). Hillsdale, NJ: Lawrence Erlbaum Associates, Publishers.

Dai, Y., Hu, G., Xiong, H., Qiu, H., \& Yuan, X. (2020). Psychological impact of the coronavirus disease 2019 (COVID-19) outbreak on healthcare workers in China. MedRxiv. doi: 10.1101/2020.03.03.20030874

Day, T., Park, A., Madras, N., Gumel, A., \& Wu, J. (2006). When is quarantine a useful control strategy for emerging infectious diseases? American Journal of Epidemiology, 163(5), 479-485. doi: 10.1093/aje/kwj056

Dong, Y., Mo, X., Hu, Y., Qi, X., Jiang, F., Jiang, Z., \& Tong, S. (2020). Epidemiological characteristics of 2143 pediatric patients with 2019 coronavirus disease in China. Pediatrics, e20200702. doi: 10.1542/peds.2020-0702

Douglas, M., Katikireddi, S. V., Taulbut, M., McKee, M., \& McCartney, G. (2020). Mitigating the wider health effects of covid-19 pandemic response. BMJ, 369, m1557. doi: 10.1136/bmj.m1557

Epidemic Stats. (2020). Coronavirus Statistics Global. Retrieved from https:// epidemic-stats.com/

Field, A. (2009). Discovering statistics using SPSS: and sex, drugs and rock'n'roll. London: SAGE Publications, Ltd.

Figueiras, M. J., \& Alves, N. C. (2007). Lay perceptions of serious illnesses: An adapted version of the Revised Illness Perception Questionnaire (IPQ-R) for healthy people. Psychology \& Health, 22(2), 143-158. doi: $10.1080 / 14768320600774462$

Gandhi, R. T., Lynch, J. B., \& del Rio, C. (2020). Mild or Moderate Covid-19. The New England Journal of Medicine. 1-9. doi: 10.1056/NEJMcp2009249

Garfin, D. R., Silver, R. C., \& Holman, E. A. (2020). The novel coronavirus (COVID-2019) outbreak: Amplification of public health consequences by media exposure. Health Psychology, 39(5), 355-357. doi: 10.1037/ hea0000875

González Ramírez, L. P., Martínez Arriaga, R. J., Hernández-Gonzalez, M. A., \& De la Roca-Chiapas, J. M. (2020). Psychological Distress and Signs of PostTraumatic Stress in Response to the COVID-19 Health Emergency in a Mexican Sample. Psychology Research and Behavior Management, 13, 589-597. doi: 10.2147/PRBM.S259563

Hagger, M. S., \& Orbell, S. (2005). A confirmatory factor analysis of the revised illness perception questionnaire (IPQ-R) in a cervical screening context. Psychology \& Health, 20(2), 161-173. doi: 10.1080/0887044042000334724

Hernández-Sampieri, R., Fernández-Collado, C., \& Baptista-Lucio, P. (2014). Metodología de la investigación. México: Mc Graw-Hill.

Holmes, E. A., O'Connor, R. C., Perry, V. H., Tracey, I., Wessely, S., Arseneault, L., ... Bullmore, E. (2020). Multidisciplinary research priorities for the COVID-19 pandemic: a call for action for mental health science. The Lancet Psychiatry, 7(6), 547-560. doi: 10.1016/S2215-0366(20)30168-1
Lai, J., Ma, S., Wang, Y., Cai, Z., Hu, J., Wei, N., ... Hu, Z. (2020). Factors associated with mental health outcomes among health care workers exposed to coronavirus disease 2019. JAMA Network Open, 3(3), e203976. doi: 10.1001/ jamanetworkopen.2020.3976

Leventhal, H., Meyer, D., \& Nerenz, D. (1980). The common sense representation of illness danger. In Rachman, S. (Ed). Contributions to Medical Psychology, Volume II, (pp. 7-30). UK: Pergamon Press Ltd.

Lugo-González, I. V., Fernández-Vega, M., Pérez-Bautista, Y. Y., \& Vega-Valero, C. Z. (2020). Propiedades psicométricas del Cuestionario Revisado de Percepción de Enfermedad (IPQ-R) en adultos mexicanos con asma. Revista Digital Internacional de Psicología y Ciencia Social, 6(2), 388-413.

Lunn, P. D., Belton, C. A., Lavin, C., McGowan, F. P., Timmons, S., \& Robertson, D. A. (2020). Using Behavioral Science to help fight the Coronavirus. Journal of Behavioral Public Administration, 3(1). doi: 10.30636/jbpa.31.147

Méndez, I., Namihira, D., Moreno, L., \& Sosa, C. (2001), El protocolo de investigación. Lineamientos para su elaboración y análisis, (2a Ed.). México, DF.: Editorial Trillas.

Molero Jurado, M. M., Herrera-Peco, I., Pérez-Fuentes, M. C., \& Gázquez Linares, J. J. (2020). Análisis de la amenaza percibida por la COVID-19 en población española. Atención Primaria, 52(7), 515-516. doi: 10.1016/j.aprim.2020.05.001

Mora, P. A., \& McAndrew. L. M. (2013). Common-sense model of self-regulation. In Gellman, M. D., \& Turner, J. R. (Eds.). Encyclopedia of Behavioral Medicine, (pp. 460-467). New York: Springer. doi: 10.1007/978-1-4419-1005-9

Moss-Morris, R., Weinman, J., Petrie, K., Horne, R., Cameron, L., \& Buick, D. (2002). The Revised Illness Perception Questionnaire (IPQ-R). Psychology \& Health, 17(1), 1-16. doi: 10.1080/08870440290001494

Muñiz, C., \& Corduneanu, V. I. (2020). Percepción de riesgo y consumo mediático durante el inicio de la pandemia de COVID-19 en México. Más poder local, (41), 44-47. Retrieved from https://dialnet.unirioja.es/servlet/ articulo? codigo $=7407223$

National Institute of Allergy and Infectious Diseases [NIAID]. (2020). Coronaviruses. Retrieved from https://www.niaid.nih.gov/diseases-conditions/coronaviruses

Orellana, C. I., \& Orellana, L. M. (2020). Predictores de síntomas emocionales durante la cuarentena domiciliar por pandemia de COVID-19 en El Salvador. Actualidades en Psicología, 34(128), 103-120. doi: 10.15517/ AP.V34I128.41431

Pacheco-Huergo, V., Viladrich, C., Pujol-Ribera, E., Cabezas-Peña, C., Núñez, M., Roura-Olmeda, P., ... del VAL, J. L. (2012). Percepción en enfermedades crónicas: Validación lingüística del Illness Perception Questionnaire Revised y del Brief Illness Perception Questionnaire para la población española. Atención Primaria, 44(5), 280-287. doi: 10.1016/j.aprim.2010.11.022

Pedrosa, I., Juarros-Basterretxea, J., Robles-Fernández, A., Basteiro, J., \& GarcíaCueto, E. (2015). Pruebas de bondad de ajuste en distribuciones simétricas ¿qué estadístico utilizar? Universitas Psychologica, 14(1), 15-24. doi: 10.11144/ Javeriana.upsy14-1.pbad

Pérez-Bautista, Y. Y., \& Lugo-González, I. V. (2017). Aplicación de un instrumento de conducta sexual a través de dos métodos de recolección de datos. Trabajo presentado en el Sexto Seminario Internacional sobre Comportamiento y Aplicaciones (SINCA), 15 noviembre. Tlaxcala, México. Retrieved from http:// seminariosinca.com/sinca6.html

Pérez-Fuentes, M. C., Molero Jurado, M. M., Oropesa Ruiz, N. F., Martos Martínez, Á., Simón Márquez, M. M., Herrera-Peco, I., \& Gázquez Linares, J. J. (2020). Questionnaire on Perception of Threat from COVID-19. Journal of Clinical Medicine, 9(4), 1196-1207. doi: 10.3390/jcm9041196

Pérez-Gay Juárez, F., Reynoso-Alcántara, V., Contreras-Ibáñez, C., Flores González, R., Castro-López, C., Martínez, L. \& Grupo COVIDiSTRESS México (2020). Evaluación del Estrés frente a la Pandemia del COVID-19 en población mexicana. Proyecto Internacional COVIDISTRESS. Reporte descriptivo de datos recolectados del 30 de Marzo al 30 de Abril, 2020. Retrieved from https://www. uv.mx/centrodeopinion/files/2020/05/Reporte-Descriptivo-para-OSF2.pdf

Petrie, K., \& Weinman, J. (2006). Why illness perceptions matter. Clinical Medicine, 6(6), 536-539. doi: 10.7861/clinmedicine.6-6-536

Petrie, K., \& Weinman, J. (2012). Patients' perceptions of their illness: The dynamo of volition in health care. Current Directions in Psychological Science, 21(1), 60-65. doi: 10.1177/0963721411429456 
Rubin, G. J., Amlôt, R., Page, L., \& Wessely, S. (2009). Public perceptions, anxiety, and behaviour change in relation to the swine flu outbreak: cross sectional telephone survey. BMJ, 339, b2651. doi: 10.1136/bmj.b2651

Rubin, G. J., Potts, H. W. W., \& Michie S. (2010). The impact of communications about swine flu (influenza A H1N1v) on public responses to the outbreak: results from 36 national telephone surveys in the UK. Health Technology Assessment, 14(34), 183-266. doi: 10.3310/hta14340-03

Sandín, B., Valiente, R. M., García-Escalera, J., \& Chorot, P. (2020). Impacto psicológico de la pandemia de COVID-19: Efectos negativos y positivos en población española asociados al periodo de confinamiento nacional. Revista de Psicopatología y Psicología Clínica, 25(1), 1-22. doi: 10.5944/rppc.27569

Secretaría de Salud [SSa]. (2020). Todo sobre el COVID-19. Retrieved from https:// coronavirus.gob.mx/

Shacham, M., Hamama-Raz, Y., Kolerman, R., Mijiritsky, O., Ben-Ezra, M., \& Mijiritsky, E. (2020). COVID-19 factors and psychological factors associated with elevated psychological distress among dentists and dental hygienists in Israel. International Journal of Environmental Research and Public Health, 17(8), 2900. doi: 10.3390/ijerph17082900

Stirratt, M. J., Dunbar-Jacob, J., Crane, H. M., Simoni, J. M., Czajkowski, S., Hilliard, M. E., ... Nilsen, W. J. (2015). Self-report measures of medication adherence behavior: recommendations on optimal use. Translational Behavioral Medicine, 5(4), 470-482. doi: 10.1007/s13142-015-0315-2

Taylor, S. (2019). The Psychology of Pandemics: Preparing for the Next Global Outbreak of Infectious Disease. Cambridge Scholars Publishing.
Urzúa, A., Vera-Villarroel, P., Caqueo-Urízar, A., \& Polanco-Carrasco, R. (2020). La Psicología en la prevención y manejo del COVID-19. Aportes desde la evidencia inicial. Terapia Psicológica, 38(1), 103-118. doi: 10.4067/S071848082020000100103

Verity, R., Okell, L. C., Dorigatti, I., Winskill, P., Whittaker, C., Imai, N., ... Ferguson, N. (2020). Estimates of the severity of coronavirus disease 2019: a model-based analysis. The Lancet Infectious Diseases, 20(6), 669-677. doi: 10.1016/S14733099(20)30243-7

Wang, C., Pan, R., Wan, X., Tan, Y., Xu, L., Ho, C. S., \& Ho, R. C. (2020). Immediate psychological responses and associated factors during the initial stage of the 2019 coronavirus disease (COVID-19) epidemic among the general population in China. International Journal of Environmental Research and Public Health, 17(5), 1729. doi: 10.3390/ijerph17051729

West, R., Michie, S., Rubin, G. J., \& Amlôt, R. (2020). Applying principles of behaviour change to reduce SARS-CoV-2 transmission. Nature Human Behaviour, 4, 451-459. doi: 10.1038/s41562-020-0887-9

Wu, X., Lau, J. T., Mak, W. W., Gu, J., Mo, P. K., \& Wang, X. (2018). How newly diagnosed HIV-positive men who have sex with men look at HIV/AIDSvalidation of the Chinese version of the revised illness perception questionnaire. BMC Infectious Diseases, 18(1), 2. doi: 10.1186/s12879-017-2902-y

Yang, S., \& Cho, S. I. (2017). Middle East respiratory syndrome risk perception among students at a university in South Korea, 2015. American Journal of Infection Control, 45(6), e53-e60. doi: 10.1016/j.ajic.2017.02.013 